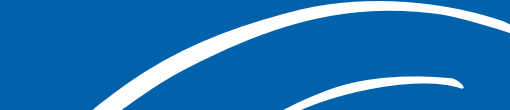 AGUA Y TERRITORIO
}

\section{¿Qué es lo que puede el agua? \\ Límites y posibilidades de las prácticas políticas para el acceso y defensa del agua como derecho en Argentina}

\author{
What is the potential of water? Limits and possibilities of the political practices \\ for the access and defense of water as a right (Argentina) \\ Cecilia Carrizo; Mauricio Berger \\ Universidad Nacional de Córdoba. Córdoba, Argentina. cecicarrizosineiro@yahoo.com.ar; mauricio.berger@gmail.com
}

\begin{abstract}
Resumen - El trabajo se orienta a visibilizar la trama de relaciones políticas entre los espacios públicos ciudadano y estatal, que operan en torno a la garantía del agua como un derecho humano. Partimos de las luchas ciudadanas por el agua en situaciones de contaminación, como espacios de interacción privilegiados, en los que la ciudadanía invoca/revoca las instituciones vigentes bregando por la vigencia de los derechos. A través de dos estudios de caso en las provincias de Córdoba y Río Negro en Argentina, el artículo explora cómo la estructura institucional de los estados provinciales actúa a la vez como factor posibilitante y/o restrictivo tanto de las prácticas de los funcionarios de los distintos poderes públicos en lo que hace a la regulación y el control de la contaminación, así como también de las condiciones de ejercicio de los derechos ciudadanos. Visualizamos diferencias notables en lo que hace a las garantías institucionales, los desarrollos organizacionales, los procedimientos, los recursos y las prácticas conectadas con la gestión del agua entre las dos provincias estudiadas. El artículo concluye con una reflexión sobre los límites y posibilidades que confrontan las esferas públicas estatal y ciudadana en la búsqueda de una política democrática de garantía del derecho al agua que supere lecturas y prescripciones tecnocráticas.
\end{abstract}

Abstract - This work aims to give visibility to the web of political relationships between the public spaces occupied by the citizens and the State seeking to guarantee the human right to water. We focus first on citizens' struggles over water in situations of environmental pollution as privileged spaces of interaction in which citizens both rely on and challenge the existing institutions in their search to make rights count. The article is based on two case studies carried out in the provinces of Cordoba and Rio Negro, Argentina, and explores how the institutional structures of provincial states can either make possible or restrict both the practices of public agents in the regulation and control of water pollution and the exercise of citizenship rights. We visualize significant differences in relation to institutional guarantees, organizational development, proceedings, resources, and practices related to water management in the two provinces. The article concludes with a reflection on the limits and possibilities facing the State and citizen's public spheres in the search for a democratic politics that guarantees the right to water and goes beyond technocratic perspectives and prescriptions.

Palabras clave: agua, ciudadanía, contaminación, medio ambiente, Estado, garantías, Argentina

Keywords: water, citizenship, pollution, environment, State, guarantees, Argentina

Información Artículo: Recibido:10 octubre 2013

Revisado: 30 noviembre 2013

Aceptado: 15 enero 2014

(c) Universidad de Jaén / Seminario Permanente Agua, Territorio y Medio Ambiente (CSIC) 